\title{
Polystyrene concrete as the structural thermal insulating material
}

Makhmud Kharun*, Alexander P. Svintsov

Department of Civil Engineering, RUDN University, Moscow, Russia

\section{A R T I C L E I N F O}

\section{Article history:}

Received 11 January 2017

Received in revised form

25 July 2017

Accepted 29 July 2017

Keywords:

Polystyrene concrete

Density

Exfoliation

Strength

Thermal conductivity

\begin{abstract}
A B S T R A C T
Polystyrene concrete is an effective and relatively inexpensive insulating and structural material. Works of many specialists are devoted to develop the composition of polystyrene concrete mixture and also to study the physical and mechanical, thermal and technological properties. One of the major problems in production of polystyrene concrete mixture and in formation of its products is the exfoliation property due to the different weight of included components. To overcome this disadvantage, various reinforcing materials, plasticizing and air-entraining additives are added in the polystyrene concrete mixture. We developed a reinforced polystyrene concrete mixture which includes expanded polystyrene, crushed polystyrene, Portland cement type I, gypsum, gaize, chrysotile asbestos fiber, plasticizer aqueous solution of polyacrylamide, carboxymethyl cellulose, tartaric acid, saponified wood resin and water for mixing. The developed composition allows obtaining the polystyrene concrete mix in a simple method with a uniform distribution of granules in volume and with minimal shrinkage deformations, without exfoliation and without grasping within the predictable time that is sufficient for the transport from the production place to the construction site. Our study established that the compressive strengths of test samples (D200, D300, D400, D500, D600, D700, D800, D900, D1000, D1100 kg/m³) are in the range of $0.28 \mathrm{MPa}$ to $4.22 \mathrm{MPa}$ in average, and the thermal conductivity 0.073 to $0.3 \mathrm{~W} /\left(\mathrm{m} .{ }^{\circ} \mathrm{C}\right)$ depending on the average density of polystyrene concrete. The developed polystyrene concrete mix can be used for the production of thermal insulating and structural thermal insulating material of buildings of various purposes.
\end{abstract}

(C) 2017 The Authors. Published by IASE. This is an open access article under the CC BY-NC-ND license (http://creativecommons.org/licenses/by-nc-nd/4.0/).

\section{Introduction}

Polystyrene concrete is a lightweight composite material, widely used in construction. Depending on the composition the polystyrene concrete can be used as the thermal and sound insulation and/or structural material. The main components of polystyrene concrete are the crushed or expanded polystyrene, mineral binder and water, and various additives provide the additional properties to it. Airentraining additives and reinforcing fibers are used to prevent the exfoliation of polystyrene concrete mixture due to a significant difference in density of polystyrene and mineral binder. The reinforcing fibers not only contribute to stabilize the mixtures, but also reduce the shrinkage deformation of polystyrene concrete. Basalt fibers, glass fiber, that

\footnotetext{
* Corresponding Author.

Email Address: miharun@yandex.ru (M. Kharun) https://doi.org/10.21833/ijaas.2017.010.007

2313-626X/C 2017 The Authors. Published by IASE.

This is an open access article under the CC BY-NC-ND license

(http://creativecommons.org/licenses/by-nc-nd/4.0/)
}

have good adhesion to the mineral binder, are used as the reinforcement material.

In order to reduce the setting time of mineral binder and satisfactory curing process we proposed a composition of polystyrene concrete that contains hemihydrate gypsum, cement, water and additives, and chrysotile asbestos was used as the reinforcing material. The study of physical and mechanical and thermal characteristics of the proposed polystyrene concrete of different densities was carried out.

\section{Analysis of the stated issue}

One of the major problems of contemporary construction is the construction of buildings with high energy-saving characteristics. For this purpose, the polystyrene concrete mixtures based on mineral binder are widely used.

Various additives and reinforcing fibers are used to create a homogeneous polystyrene concrete mixture (Urkhanova and Tsydypova, 2014; Puzanov, 2007; Rakhmanov et al., 2000; Svintsov et al., 2016).

Leshchenko and Semko (2015), and Rakhmanov (2011) revealed that the thermal conductivity of 
polystyrene concrete is $10-30 \%$ lower, but the compressive strength is $10-15 \%$ higher than the cellular concrete. Therefore, polystyrene concrete has good prospects of use as the thermal and sound insulation material. Modern technological provision, which includes the mixing, forming and calibrating equipment, as well as modifiers of polystyrene concrete mixture, allows obtaining the polystyrene concrete products with the desired physical and mechanical and thermal characteristics.

One of the features of polystyrene concrete mixture is its exfoliation during the production. It is due to the great difference of components weight and the hydrophobicity of polystyrene that is used as the aggregate. Zhurba et al., (2007), and Urkhanova and Tsydypova (2014) recommend to use various additives to increase the hydrophilicity of expanded polystyrene. It is shown that the average density of structural thermal insulating polystyrene concrete is reached $900-1000 \mathrm{~kg} / \mathrm{m}^{3}$, thermal conductivity $0.23 \mathrm{~W} / \mathrm{m} .{ }^{\circ} \mathrm{C}$, compressive strength - 4.5-11 MPa, water absorption - 4.2\%. Ershov and Vilman (2012) revealed that the high thermal properties of expanded polystyrene allow using it successfully as a facing material for high-rise buildings. Cement binder based on thermal insulating (with density of $150-300 \mathrm{~kg} / \mathrm{m}^{3}$ ) and structural thermal insulating (with density of $350-550 \mathrm{~kg} / \mathrm{m}^{3}$ ) polystyrene concrete was used for facing.

Polystyrene concrete allows improving the thermal insulation properties of exterior walls of monolithic expanded clay concrete. After the extraction of channel shapers, the polystyrene concrete mixture is placed in the vertical channels of the walls that allow increasing the thermal insulation characteristics by an average of $65 \%$. Polystyrene concrete of density grade D250 is recommended to fill the channels (Remezova, 2009).

One of the options of using the polystyrene concrete for thermal protection of exterior walls is the technology of construction of triple-layer sandwich panels (Kirichenko and Krylov, 2013). Rakhmanov (2009, 2011), and Dvorkin et al. (2015) recommended some methods to obtain materials with the specified properties. The proposed designed models of polystyrene concrete bound its strength with density, and also with characteristics of major components and special additives.

Study of influence of hydro-thermal-power field on curing rate of polystyrene concrete was presented by Sokolov and Beglyarov (2015). They showed that under these conditions the polystyrene concrete obtains a uniformly distributed fine pore structure.

Study of the physical and mechanical and the thermal characteristics of polystyrene concrete were carried out by the experts of different countries. Ayse and Filiz (2016), San-Antonio-Gonzalez et al. (2015), and Cui et al. (2016) have presented some results of study of strength and thermal characteristics of polystyrene concrete with expanded polystyrene. Ferrándiz-Mas and GarcíaAlcocel (2013), and Sadrmomtazi et al. (2012) revealed that the quantity of expanded polystyrene, Portland cement, plasticizers and various additives have significant effect on the strength of polystyrene concrete in axial compression and in tensile bending. It was established that the addition of rice husk and waste propylene fibers allow to obtain a moderate strength grade for structural material. Some structural elements of building can be influenced by the dynamic load. In this regard a study of the dynamic properties of polystyrene concrete was performed by Chen et al. (2015). Tang et al. (2014) studied the creep behavior of polystyrene concrete. It was established that the creep deformation of polystyrene concrete increases with the increase of quantity of polystyrene aggregate in the mixture.

The use of expanded polystyrene for manufacturing of various types of packaging contributes to the environmental stress in all countries. In this regard, re-use of crushed or regenerated polystyrene as a lightweight aggregate of construction material is an important task. The research results of physical and mechanical properties of polystyrene concrete made of the reinforced and unreinforced mixtures are presented in the publications of Zhurba et al (2007), Urkhanova and Tsydypova (2014), Ferrándiz-Mas et al. (2016), Wang and Meyer (2012), and Bhutta et al. (2011). Compositions containing up to $60 \%$ polystyrene, as well as a low content of Portland cement and additives are studied. The studied compositions of polystyrene concrete are advisable to use as a structural thermal insulating material.

Polystyrene concrete, as a thermal insulating material, is used not only in the form of piece elements, insulating layers, but also in the construction of monolithic structures (Yarmakovsky et al., 2014). Highly lightweight polystyrene concrete is also placed in the permanent formwork, which can significantly increase the product ability of manufacturing industry of precast walls.

Analysis of publications of Kovylin and Fokin (2010), Chernyshov et al. (2009), and Karpov et al. (2014) shows that currently the works on improving the polystyrene concrete compositions are actively conducting. In this regard, it is important to assess the thermal characteristics of this or that proposed formulation of polystyrene concrete. Several works are devoted to the methods for determining the thermal characteristics. Results of the study of thermo-physical characteristics by the methods of regularized thermal regime and nondestructive testing are presented. The proposed methods allow determining the thermos-physical characteristics of the test material with the required accuracy for engineering calculations.

The use of polystyrene concrete allows solving the problem of energy saving in buildings by improving the thermal characteristics of external walls. As the components it is advisable to use waste of various industrial and business activities, which will reduce the anthropogenic load on the environment. Nowadays expanded polystyrene is widely used for packaging of electrical equipment, 
household appliances and others. After use, part of this packaging material is forwarded for recycling, but part - to the dump as the long-term environmental pollutants. The existing technologies for processing the expanded polystyrene allow reusing it as an aggregate in various lightweight concrete compositions. The applied crushers allow to keep the spherical shape of grains with the size of 0.5 to $4-6 \mathrm{~mm}$. Polystyrene concrete mixtures are based on hydraulic binders, expanded or crushed polystyrene with additives to provide various properties to the resulting products (Puzanov, 2007; Rakhmanov et al., 2000; Svintsov et al., 2016).

The most typical advantage of the compositions of polystyrene compounds is their high thermal insulation capacity. The most important disadvantages of this material is the exfoliation during placing, and the shrinkage cracks during curing. To emphasize the positive properties of expanded polystyrene concrete it is advisable to develop a composition mix, free from the identified disadvantages. It will allow more extensive use of polystyrene concrete in contemporary construction and reuse of crushed polystyrene, thereby reducing the anthropogenic load on the environment.

\section{Materials and methods of research}

Polystyrene concrete is a composite material consisting of mineral binder, expanded polystyrene beads or crushed polystyrene, water, and air entraining, plasticizing and structure-forming additives, and also reinforcing fibers.

As part of the study the following materials were used to obtain the reinforced polystyrene concrete mixture: expanded polystyrene crushed polystyrene, Portland cement type I, gypsum, gaize, chrysotile asbestos fiber, plasticizer aqueous solution of polyacrylamide, carboxymethyl cellulose, tartaric acid, saponified wood resin and water for mixing.

According to the formulation the production of polystyrene concrete mixture comprises the stirring of polystyrene, chrysotile asbestos fiber and polyacrylamide which was added with the mixing water. And then a mix of Portland cement and hemihydrate gypsum was added during the stirring of above-mentioned blend. Ten different mixtures were accepted with the calculated density of D200, D300, D400, D500, D600, D700, D800, D900, D1000, $\mathrm{D} 1100 \mathrm{~kg} / \mathrm{m} 3$ for the study of the physical and mechanical properties and thermal conductivity of polystyrene concrete.

Cubes with the dimensions of $100 \times 100 \times 100 \mathrm{~mm}$ were produced from the stated mixtures. Study of the physical and mechanical characteristics and the thermal conductivity of polystyrene concrete were carried out with the using of hydraulic press of 50 $\mathrm{kN}$ and test bench for the thermal conductivity accordingly.

Mathematical processing of the experimental data was carried out on the basis of theory of probability and mathematical statistics.
Using of the indicated materials, tools and research methods allowed us to obtain the statistically significant results of experimental study with the reliability of $\alpha \approx 0.95$.

\section{Results and discussion}

In the framework of our study the following physical and mechanical properties were found out: density, compressive strength and thermal conductivity.

We developed a polystyrene concrete mixture with controlled setting time and hardening. Its exfoliation was not observed during the production and laying the mixture in the forms. Controlling of setting time is carried out by varying the quantity of added tartaric acid. Fig. 1 shows the general view of samples produced from the mixture of polystyrene concrete.

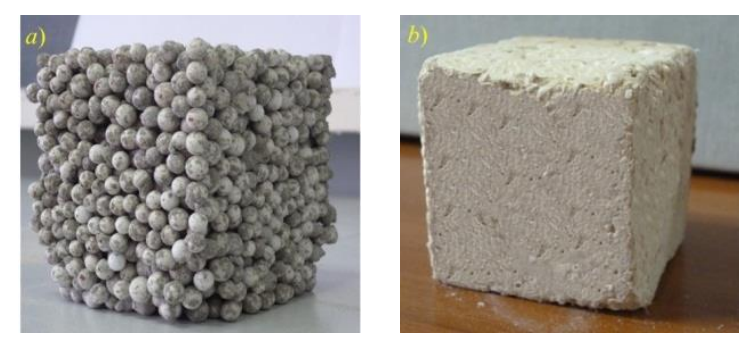

Fig. 1: Samples of polystyrene concrete mixture (a) Average density of D200 on the expanded polystyrene beads; b) average density of D600 on the crushed polystyrene)

Polystyrene concrete mixture with the addition of aqueous solution of polyacrylamide as a structureforming component and chrysotile asbestos fiber as a reinforcing element stirs well and forms without exfoliation. Shrinkage deformations were not marked during the curing period of products.

Our study established that the compressive strengths of test samples are in the range of 0.28 $\mathrm{MPa}$ to $4.22 \mathrm{MPa}$ in average, and the thermal conductivity -0.073 to $0.3 \mathrm{~W} /\left(\mathrm{m} .{ }^{\circ} \mathrm{C}\right)$ depending on the average density of polystyrene concrete.

In the study of physical and mechanical and thermal characteristics of polystyrene concrete we analyzed the compressive strength and thermal conductivity depending on the designed density of the material. Fig. 2 shows the diagram of compressive strength, based on the experimental data, depending on the designed density of polystyrene concrete.

Analysis of the diagram shows the presence of nonlinear coupling of the compressive strength with the density of polystyrene concrete. With the increasing of density of polystyrene concrete the compressive strength increases exponentially with the coefficient of determination $\mathrm{R}^{2}=0.994$. Increasing the strength of polystyrene concrete is caused not only by the quantity of mineral binder, and also the quantity of structure-forming and mineral additives, as well as the alkali-resistant reinforcing fiber of chrysotile asbestos. Fig. 3 shows 
the changes in the thermal conductivity depending on the density of polystyrene concrete.

Density of polystyrene concrete depends on its structure and the ratio of aggregate and binder. Increasing the cement stone matrix leads to the fact that the aggregate grains bound more strongly with the cement stone. This matrix serves as the main conduit in heat transfer. With the increasing of density of polystyrene concrete the thermal conductivity increases. The diagram shows that the changes in thermal conductivity of polystyrene concrete are characterized by a significant spread of values. The least variation of data is observed at the density of D200-D600 and D900-D1100 kg/m . Samples with the density of D700-D800 $\mathrm{kg} / \mathrm{m}^{3}$ is characterized a large variation of the thermal conductivity values. It is due to a large unequal distribution of granules in the array of cement stone, despite the lack of exfoliation of mixture in the formation of samples.

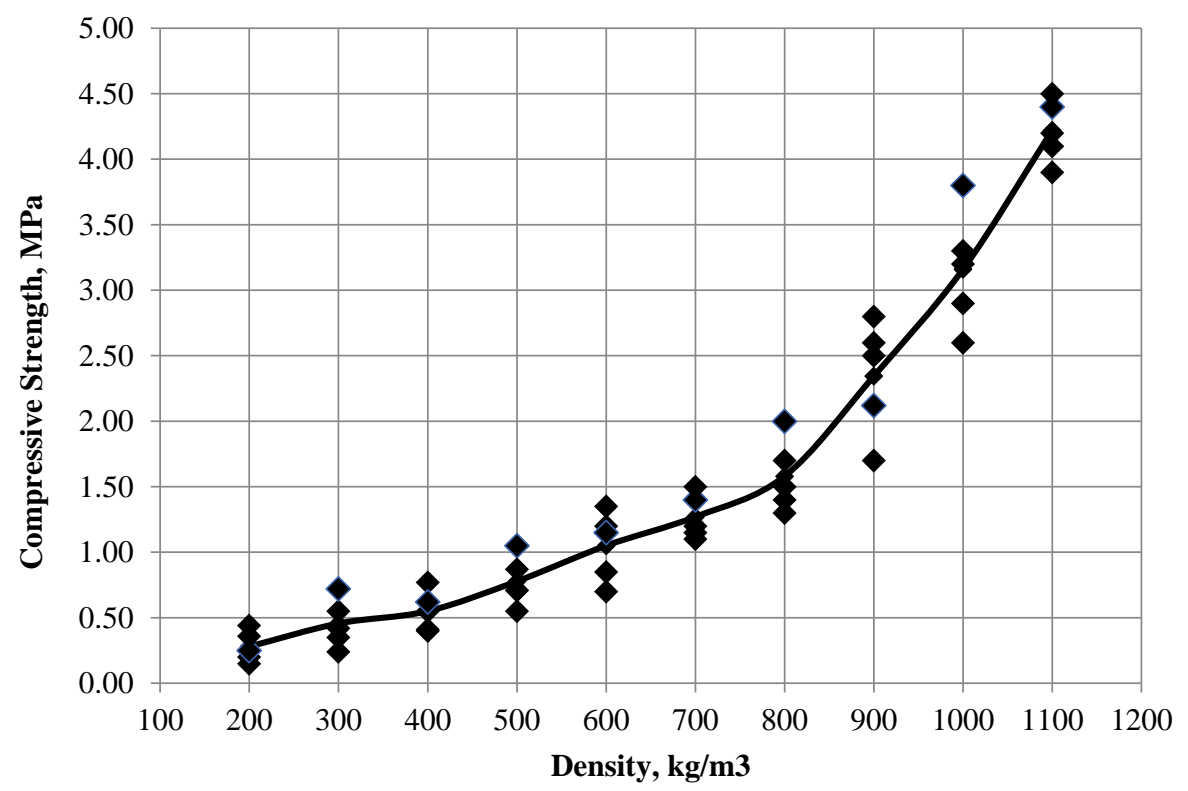

Fig. 2: Changes in compressive strength of polystyrene concrete with different density

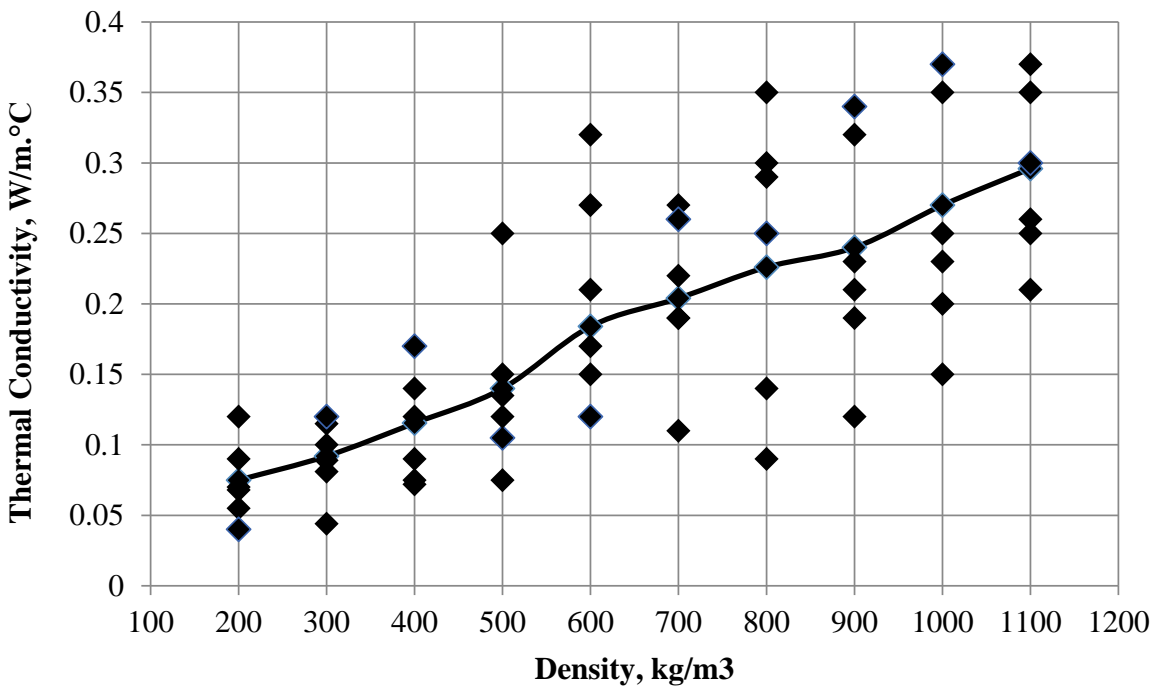

Fig. 3: Changes in thermal conductivity depending on the density of polystyrene concrete

Thus, the developed polystyrene concrete mixture is characterized by good flow ability without exfoliation. To obtain it the expanded polystyrene beads (for the density grade of D450 and lower), and the crushed polystyrene from waste polystyrene (for the density grade of D500 and higher) can be used. Application of polystyrene concrete based on the proposed composition will allow solving the tasks of not only the heat-insulating, but also the structural thermal insulating material.

\section{Conclusion}

As a result of experimental study a mixture of polystyrene, reinforced with chrysotile asbestos fibers, was developed. A mix of hemihydrate gypsum and Portland cement was used as the mineral binder. Additives, which consist of super plasticizer, gaize, polyacrylamide and tartaric acid, are intended to provide to the polystyrene concrete mixture the properties of plasticity and equal flow ability, and also controllability of setting time. 
As a result of experimental study it is established that the compressive strengths of test samples are in the range of $0.28 \mathrm{MPa}$ to $4.22 \mathrm{MPa}$ in average, and the thermal conductivity -0.073 to $0.3 \mathrm{~W} / \mathrm{m} .{ }^{\circ} \mathrm{C}$ at the density of 200 to $1100 \mathrm{~kg} / \mathrm{m} 3$. The obtained results allow considering that the developed polystyrene concrete mixture can be used in production due to the equal flow ability, the lack of exfoliation and the simplicity of production technology and formation of products.

\section{References}

Ayse KAYA and Filiz KAR (2016). Properties of concrete containing waste expanded polystyrene and natural resin. Construction and Building Materials, 105: 572-578.

Bhutta MAR, Ohama Y, and Tsuruta K (2011). Strength properties of polymer mortar panels using methyl methacrylate solution of waste expanded polystyrene as binder. Construction and Building Materials, 25(2): 779-784.

Chen W, Hao H, Hughes D, Shi Y, Cui J, and Li ZX (2015). Static and dynamic mechanical properties of expanded polystyrene. Materials and Design, 69: 170-180.

Chernyshov VN, Golikov DO, and Chernyshov AV (2009). Метод и система оперативного контроля теплофизических характеристик строительных материалов [Теchnique and system for operation monitoring of thermo-physical properties of construction materials]. Transactions of Tambov State Technical University, 15(1): 85-91. Available online at: http://vestnik.tstu.ru/rus/t_15/pdf/15_1_012.pdf

Cui C, Huang Q, Li D, Quan C, and Li H (2016). Stress-strain relationship in axial compression for EPS concrete. Construction and Building Materials, 105: 377-383.

Dvorkin LI, Dvorkin OL, Garnitsry YuV, and Kochkarev GV (2015). Методика проектирования состава полистиролбетона с заданными свойствами [The design method of polystyrene composition with the desired properties]. Concrete Technologies, 1-2: 42-46. Available online at: https://elibrary.ru/item.asp?id=23067683

Ershov MN and Vilman YA (2012). Технология облицовки 25этажного монолитного железобетонного жилого дома. стройка глазами ученых [Technology of facing of the 25storied cast-in-situ reinforced concrete residential building, Construction in the eyes of scientists]. Mechanization of Construction, 10: 24-31. Available online at: https://elibrary.ru/item.asp?id=18036356

Ferrándiz-Mas V and García-Alcocel E (2013). Durability of expanded polystyrene mortars. Construction and Building Materials, 46: 175-182.

Ferrándiz-Mas V, Sarabia LA, Ortiz MC, Cheeseman CR, and GarcíaAlcocel E (2016). Design of bespoke lightweight cement mortars containing waste expanded polystyrene by experimental statistical methods. Materials and Design, 89: 901-912.

Karpov DF, Pavlov MV, Koryukin SI, Mnushin NV, and Sorogin AS (2014). Устройство и способ комплексного определения основных теплофизических свойств строительных материалов [Apparatus for measuring thermophysical properties of construction materials]. Transactions of Tomsk State University of Architecture and Building, 3(44): 135-144. Available online at: https://elibrary.ru/item.asp?id= 21613799

Kirichenko VA and Krylov BA (2013). Новая технология изготовления трехслойных панелей для наружных стен с высокими теплозащитными свойствами [New technology for manufacturing three-layer panels for external walls with high heat-protective properties]. Concrete Technologies, 6(83): 45-47. Available online at: https://elibrary.ru/item.asp?id=22517270
Kovylin AV and Fokin VM (2010). Методика определения коэффициентов теплопроводности, теплоусвоения, тепловой инерции, температуропроводности и объемной теплоемкости строительных и теплоизоляционных материалов методом неразрушающего контроля [Methodology of determination of heat conductivity, thermal absorptivity, coefficient of thermal inertia, thermal conductivity and volumetric heat capacity of construction and heat-insulating materials using the nondestructive method of testing]. Transactions of Volgograd State University of Architecture and Building, 19: 112-117. Available online at: https://elibrary.ru/item.asp?id= 15164682

Leshchenko MV and Semko VA (2015). Thermal characteristics of the external walling made of cold-formed steel studs and polystyrene concrete. Magazine of Civil Engineering, 8(60): 44-55. https://doi.org/10.5862/MCE.60.6

Puzanov BA (2007). Армированная полистиролбетонная смесь, способ приготовления смеси, способ изготовления теплоизоляционных изделий, панель и блок (варианты) [Reinforced polystyrene concrete mixture, the method of producing the mixture, the ability to manufacturing the insulation products, panel and block (options)]. Patent of the Russian Federation No. 2309134. Available online at: http://www.freepatent.ru/patents/2309134

Rakhmanov VA (2009). Расчетный метод определения состава полистиролбетона с требуемой прочностью и минимальной плотностью [Calculation method of determination of polystyrene concrete compositon with required strength and minimal density]. Industrial and Civil Engineering, 7: 45-47. Available online at: https://elibrary.ru/item.asp?id=12567548

Rakhmanov VA (2011). Инновационная технология полистиролбетона с оптимальными свойствами [Innovative technology of polystyrene concrete with optimal properties]. Construction Materials, Equipment, Technologies of XXI Century, 9(152): 37-41. Available online at: http://stroymat21.ru/pdf/2011_09/37-41.pdf

Rakhmanov VA (2011). Энергосбережение в строительстве на основе применения инновационной технологии изготовления особо легких полистиролбетонов [Energy saving in construction through the application of innovative manufacturing technology of highly lightweight polystyrene concrete]. Industrial and Civil Engineering, 8: 61-62. Available online at: https://elibrary.ru/item.asp?id=16559168

Rakhmanov VA, Rossovsky VN, Kozlovsky AI, Deviatov VV, and Lanyuk AN (2000). Состав для изготовления полистиролбетонной смеси [Component for the production of polystyrene concrete mixture]. Patent of the Russian Federation No. 2150446. Available online at: http://www.freepatent.ru/patents/2150446

Remezova TI (2009). Технология возведения теплоэффективных керамзитобетонных монолитных наружных стен с вертикальными цилиндрическими каналами, заполненными полистиролбетоном [The technology of erecting the thermo-effective claydite concrete monolithic external walls with vertical cylyndrical canals filled with polystyrene-concrete]. Transactions of Tomsk State University of Architecture and Building, 3: 111-117. Available online at: https://elibrary.ru/item.asp?id=12938963

Sadrmomtazi A, Sobhani J, Mirgozar MA, and Najimi M (2012). Properties of multi-strength grade EPS concrete containing silica fume and rice husk ash. Construction and Building Materials, 35: 211-219.

San-Antonio-Gonzalez A, Merino MDR, Arrebola CV, and VilloriaSaez P (2015). Lightweight material made with gypsum and extruded polystyrene waste with enhanced thermal behaviour. Construction and Building Materials, 93: 57-63.

Sokov VN and Beglyarov AE (2015). Особенности формирования структуры бетона в гидротеплосиловом поле [Specific features of concrete structure formation in a hydro-heat-power field]. Scientific Review, 10(1): 139-142. 
Available online at: https://elibrary.ru/item.asp?id= 24110112

Svintsov AP, Masri GKS, Kalashnikova LG, and Egorova NA (2016). Армированная гипсополистиролбетонная смесь [Reinforced gypsum-polystyrene concrete mixture]. Patent of the Russian Federation No. 2577348. Available online at: http://www.freepatent.ru/patents/2577348

Tang WC, Cui HZ, and Wu M (2014). Creep and creep recovery properties of polystyrene aggregate concrete. Construction and Building Materials, 51: 338-343.

Urkhanova LA and Tsydypova AT (2014). Использование химических добавок, применяемых в дорожном строительстве для получения конструкционнотеплоизоляционного полистиролбетона [The use of chemical additives applied in road construction for structural heat-insulating polystyrene concrete]. Transactions of EastSiberian State University of Technology and Management, 2: 58-62. Available online at: https://elibrary.ru/item.asp?id= 21531330
Wang R and Meyer C (2012). Performance of cement mortar made with recycled high impact polystyrene. Cement and Concrete Composites, 34(9): 975-981.

Yarmakovsky VN, Kostin AN, Fotin OV, and Kondyurin AE (2014). Теплоэффективные наружные стены зданий, возводимые с использованием монолитного полистиролбетона с высокопоризованной и пластифицированной матрицей [Thermal efficiency of the exterior walls of buildings, erected with the use of polystyrene concrete reinforced with the highly pored and plasticized matrix]. Housing Construction, 6: 18-23. Available online at: https://elibrary.ru/item.asp?id= 21649241

Zhurba OV, Shchukina EG, N.V. Arkhincheeva NV, Zayakhanov ME, and Shchukin EA (2007). Конструкционнотеплоизоляционный полистиролбетон на основе регенерированного сырья [Structural insulating polystyrene concrete based on recycled raw materials]. Construction Materials, 3: 50-52. Available online at: https://elibrary.ru/item.asp?id=9474767 